\title{
In Memoriam: Dr. Sergey V. Zhirov (1966-2017)
}

\author{
Valentina Kuznetsova', Natalia Golub', Ninel Petrova', Vladimir Lukhtanov', \\ Boris Anokhin', Natalia Khabasova', Nazar Shapoval', \\ Larissa Kupriyanova', Ilya Gavrilov-Zimin'
}

I Department of Karyosystematics, Zoological Institute, Russian Academy of Sciences, Universitetskaya nab. 1, 199034 St. Petersburg, Russia

Corresponding author: Valentina Kuznetsova (valentina_kuznetsova@yahoo.com)

Academic editor: V. Gokhman | Received 16 October 2019 | Accepted 16 October 2019 | Published 21 October 2019

http://zoobank.org/2A4CBB57-6E2C-4E5F-B477-F39D776422D2

Citation: Kuznetsova V, Golub N, Petrova N, Lukhtanov V, Anokhin B, Khabasova N, Shapoval N, Kupriyanova L, Gavrilov-Zimin I (2019) In Memoriam: Dr. Sergey V. Zhirov (1966-2017). Comparative Cytogenetics 13(3): 321-324. https://doi.org/10.3897/CompCytogen.v13i3.47366

On October 26 $6^{\text {th }}, 2017$, the Cytogenetic Science suffered a stunning loss:

Dr. Sergey V. Zhirov, geneticist and cytogeneticist, passed away at the age of fifty-one.

Dr. Sergey V. Zhirov, the researcher of the Department of Karyosystematics of the Zoological Institute, Russian Academy of Sciences in St. Petersburg, died of a heart attack, on his way to the Institute. This was a sudden death, and we were shocked to learn it.

Sergey was born on June $8^{\text {th }}, 1966$ in the city of Starodub, Bryansk region, Russia, as a son of a schoolteacher and an engineer. His childhood passed in an ancient Russian city of Pskov, where Sergey graduated from a secondary school with a Gold Medal. At school, he enthusiastically studied biology, chemistry, physics, and mathematics. However, Sergey finally chose biology and, after graduating from the school, he entered the Pskov State Pedagogical Institute, the Faculty of Biology and Chemistry, and the Department of Natural Geography. After the first course, he was called up for the military service. He was doing this service at the Finnish border until 1986 and then he returned to his alma mater. Sergey's friends and tutors from the Institute recall him as a very capable, conscientious and active student. He participated in various activities of the student sci-

Copyright Kuznetsova V et al. This is an open access article distributed under the terms of the Creative Commons Attribution License (CC BY 4.0), which permits unrestricted use, distribution, and reproduction in any medium, provided the original author and source are credited. 


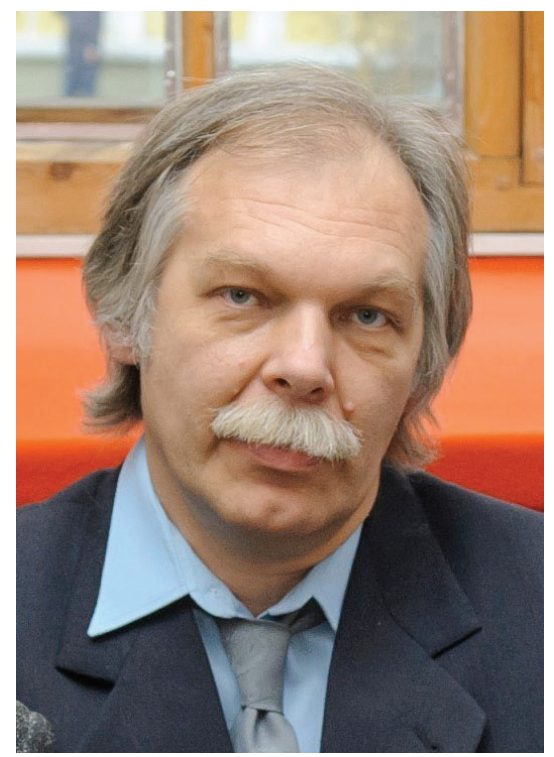

Figure I. Dr. Sergey V. Zhirov (8.VI.1966 - 26.X.2017). entific society, carrying out research projects and participating in student conferences. His Graduate Thesis entitled "The influence of electromagnetic fields on the embryogenesis of the Chudsky lake whitefish" represented an exemplary student work.

After graduating, Sergey remained at the Department of Zoology of the Institute. Being an associate professor, he organized and conducted field training of the students and supervised their research work. He wrote several manuals and used to teach at the Ecological and Biological Center. Simultaneously with the teaching activity, Sergey continued his scientific studies.

In 1989, Sergey married his classmate Diana, and in 1990, their daughter Uljana was born.

Sergey lived with a passion for science. His distinguished research career focused on studying giant polytene chromosomes of chironomid midges (Diptera, Chironomidae), including polymorphisms related to the environmental conditions. In 1991-1994, Sergey was pursuing postgraduate studies at the Herzen State Pedagogical University (St. Petersburg) and the Zoological Institute RAS. He received a PhD degree in Genetics at St. Petersburg State University with the thesis "Chromosomal and genomic polymorphism in chironomid populations of the Pskov region".

From 2008, Sergey continued his research in cytogenetics and karyosystematics of chironomids at the Department of Karyosystematics of the Zoological Institute RAS. Sergey was a talented researcher. He put forward interesting hypotheses and carefully and precisely conducted experiments to prove those hypotheses. Sergey had "golden hands" and created accurate and reliable research tools for his experiments. He published more than 20 articles in several peer-reviewed journals.

Among Sergey's many distinctions, we would like to note another two. He was a member of the Editorial Team of Comparative Cytogenetics. As a Subject Editor managing submissions on chironomid cytogenetics, he was strict but very helpful and friendly to the authors. In addition, he was a highly respected guide at the Zoological Museum of the Zoological Institute. He took his guide mission very seriously and was able to explain complex issues in a perfectly clear way. Sergey was therefore one of the most admired guides at the Museum.

Apart from Sergey's teaching and academic careers, he also was a talented person. He enjoyed literature and wrote a number of verses.

We were very fortunate to work and study together with Sergey. He will be sincerely missed by his friends and colleagues. Unfortunately, his wife outlasted Sergey for only two years; Diana passed away in October 2019. We send our heartfelt condolences to their daughter Uljana. 


\section{Main publications of Sergey V. Zhirov:}

Petrova NA, Zhirov SV (2008) Cytogenetics of Chironomus riparius L. from the fishpond in Borok village (Diptera, Chironomidae, Diptera). Tsitologia 50(6): 535-538. [In Russian with English Summary]

Petrova NA, Zhirov SV (2008) Polytene chromosomes of salivary glands of chironomids (Diptera: Chironomidae) from the Wrangel Island (Russia). Comparative Cytogenetics 2(2): $127-130$.

Petrova NA, Zhirov SV (2009) Inversion polymorphism in two Chironomidae species out of genera Chironomus and Camptochironomus (Diptera, Chironomidae, Chironomini) from different regions of Russia (Center and North-West). Vestnik of Saint Petersburg University (Series 3. Biology) 4: 29-39. [In Russian with English Summary]

Petrova NA, Zhirov SV (2010) Larva morphology, karyotype structure, and inversion polymorphism in a chironomid from the Republic of South Africa (Diptera, Chironomidae). Vestnik VOGiS 14(1): 70-78. [In Russian with English Summary]

Petrova NA, Zhirov SV, Zelentsov NI, Kachvoryan EA (2011) To the fauna of chironomids (Diptera, Chironomidae) from the Razdan River valley (Arnenia). Zoologicheskii Zhurnal 114: 445-451. [In Russian with English Summary]

Petrova NA, Zhirov SV (2011) Cytogenetic comparison of chironomid midge Glyptotendipes glaucus (Meigen, 1818) (Diptera, Chironomidae) populations from Northwest Russia and Ukraine (Chernobyl Zone). Ecological Genetics 9(2): 9-16. [In Russian with English Summary] https://doi.org/10.17816/ecogen1029-16

Petrova NA, Zhirov SV, Arutyunova KV, Arutyunova MV (2012) Morphological abnormalities of mouthparts in some species of subfamilies Orthocladiinae and Diamesinae (Diptera, Chironomidae). Biological Journal of Armenia 64(4): 48-52. [In Russian].

Zhirov SV, Petrova NA (2013) The chironomid midge Dicrotendipes sp. afr. (Diptera, Chironomidae) from the Republic of South Africa. Entomological Review 93(6): 695-702. [Originally published in Russian in Zoologicheskii Zhurnal, 2013, 92(4): 464-471] https://doi. org/10.1134/S0013873813060031

Petrova NA, Zhirov SV (2014) Characteristics of the karyotypes of three subfamilies of Chironomids (Diptera, Chironomidae: Tanypodinae, Diamesinae, Prodiamesinae) of the world fauna. Entomological Review 94(2): 157-165. [Originally published in Russian in Entomologicheskoe Obozrenie, 2013, 92(3): 505-516] https://doi.org/10.1134/ S001387381402002X

Karmokov MKh, Belyanina SI, Zhirov SV, Petrova NA (2014) Karyotype and morphology of the midge Stictochironomus crassiforceps (Kieffer) (Diptera, Chironomidae) from several parts of the Palaearctic. Entomological Review 94(9): 1229-1238. [Originally published in Russian in Entomologicheskoe Obozrenie, 2014, 93(3): 555-563] https://doi. org/10.1134/S0013873814090048

Zhirov SV, Petrova NA (2015) Karyotypes and larval morphology of three species of midges (Diptera, Chironomidae) from lakes in the Southern part of Kunashir Island. Entomological Review 95(7): 881-890. [Originally published in Russian in Entomologicheskoe Obozrenie, 2015, 94(3): 599-607] https://doi.org/10.1134/S0013873815070064 
Lobkova LE, Orel OV, Zhirov SV, Petrova NA (2015) Chironomus (Chironomus) acidophilus Keyl, 1960 (Diptera, Chironomidae, Chironominae): biology, morphology, karyotype and habitat conditions in the caldera of the Uzon Volcano (Kamchatka, Kronotsky Nature Reserve). Proceedings of the Kronotsky Nature Reserve 4: 92-119. [In Russian with English Summary]

Orel OV, Lobkova LE, Zhirov SV, Petrova NA (2015) A new record of Chironomus (Chironomus) acidophilus Keyl (Diptera, Chironomidae) from the Uzon volcanic caldera (Kronotsky Reserve, Kamchatka Peninsula, Russia), its karyotype, ecology and biology. Zootaxa 3981(2): 177-192. https://doi.org/10.11646/zootaxa.3981.2.2

Mylnikov SV, Zhirov SV (2015) Statistical approach to the problem of the taxonomic status and evolutionary potential of a non-biting midge Prodiamesa olivacea Meigen (1818) (Diptera, Chironomidae, Prodiamesinae) based on karyotype analysis. Ecological Genetics 13(1): 3-9. [In Russian with English Summary] https://doi.org/10.17816/ecogen1313-9

Petrova NA, Cornette R, Shimura S, Gusev OH, Pemba D, Kikawada T, Zhirov SV, Okuda $\mathrm{T}$ (2015) Karyotypical characteristics of two allopatric African populations of anhydrobiotic Polypedilum Kieffer, 1912 (Diptera, Chironomidae) originating from Nigeria and Malawi. Comparative Cytogenetics 9(2): 173-188. https://doi.org/10.3897/CompCytogen. v9i2.9104

Petrova NA, Zhirov SV (2015) The cytogenetic characteristic of some Palearctic populations of Holarctic midge Glyptotendipes barbipes Staeger (Diptera, Chironomidae). Tsitologia 57(11): 831-837. [In Russian with English Summary]

Zhirov SV, Mylnikov SV (2016) About approaches to studying the microevolutionary phenomena in connatural chironomids populations. Nonequilibrium of populations as stable state. Ecological Genetics 14(3): 35-46. [In Russian with English Summary] https://doi. org/10.17816/ecogen 14335-46

Petrova NA, Zhirov SV (2017) Karyotype characteristics of Chironomus fraternus Wülker and Ch. beljaninae Wülker (Diptera, Chironomidae) from Northern Russia. Entomological Review 97(6): 730-734. [Originally published in Russian in Entomologicheskoe Obozrenie, 2017, 96(3): 429-435] https://doi.org/10.1134/S0013873817060033

Petrova NA, Zhirov SV, Krasheninnikov AB (2019) Larvae morphology and karyotype structure of Chironomus sp. (Diptera, Chironomidae) from Novaya Zemlya archipelago (Russia). Entomologicheskoe Obozrenie 98(4). [In press] 